\title{
Motivation: A key to success in the foreign language classroom? A case study on vocational training and higher education English courses
}

\author{
Begoña Bellés-Fortuño*, Noemi Ollero Ramírez* \\ * Universitat Jaume I
}

\begin{abstract}
Motivation in the EFL classroom has aroused the interest of researchers in the last 20 years or so with the solely purpose of fostering students' interest and eagerness to learn a foreign a language (Gardner 2001; 2007, Dörnyei 2001, Dörnyei \& Schmidt 2001, Carrió-Pastor \& Mestre 2014 among others). This study analyses two groups of students. On the one hand, an intermediate language level Trade Course with ages ranging from 18-23 years old in a vocational training high school and a first year university degree classroom (18-21 years old), both groups in an ESP setting. We tried to observe and analyse the degree of motivation in the English as a Foreign Language classroom in a vocational training high school setting and a university class. A couple of questionnaires have been developed in order to survey these two groups of students in different educational institutions. The results show that university students learning EFL feel more motivated towards language learning than vocational training students due to several reasons that are not exclusively related to the language teacher. Relevant methodologies in which students feel they have an active role in the learning process should be considered.
\end{abstract}

Keywords: EFL, motivation, vocational training courses, higher education classroom

\section{Introduction}

Factors affecting foreign language learning are many, namely, age, sex, culture, identity, learners' variables, students' interests, etc. However, according to Dörnyei and Schmidt (2001) learner's enthusiasm, commitment and persistence are key determinants of success or failure in the process of mastering a foreign language. If this is so, how can we motivate our students to improve their English language learning? If motivation provides learners with the primary stimuli for initiating foreign language learning (Dörnyei 2001), lecturers/teachers have to consider aspects such as the structure of the course to be taught, their interactions with the students, the nature of the assignments or even classroom environment, factors which may also have a large effect on students' motivation towards the learning of a foreign/second language.

Spanish students learning English as a Foreign Language (EFL) find themselves involved in classrooms where the level of English is by no means homogeneous. Sometimes, they find themselves helpless against the English language level certification requirements and bound to the European commission language policies (European Commission 2014) and the Common European Framework of Reference for Languages (CEFR), since language certification has become a compulsory requirement for most academic applications. These factors increase the level of stress to which students are subjected to when learning a foreign language. The most recent strategic framework, Education and Training 2020 (ET2020), for European cooperation on education and training displays some common strategic objectives that the Member States have to achieve by 2020. This framework sets some priority areas such as foreign language competences. One of the objectives set for 2020 related to foreign language competence establishes that at least $50 \%$ of the Spanish students should reach an independent user language level B1 or higher (according to de CEFR) in a foreign language. Statistics in 2011 revealed that in Spain only a $26.7 \%$ of the students at the end of Secondary Education reached a B1 level or higher (Objetivos 
educativos y españoles. Informe 2013), this percentage is far from the objective of $50 \%$ set out by the European Commission for the Member States.

This situation invites reflection regarding foreign language learning issues in Spanish institutions, there is a need to analyse the scare success in foreign language teaching and find new methodologies and language teaching theories where students be the central part of the learning process. Many language teachers assume that their students a highly motivated towards the language and its culture, and therefore they come to class in a very positive attitude, but this is a wrong believe, learning a foreign language can produce a negative attitude on certain occasions (Nocon 1991, Robinson-Stuart \& Nocon 1996)

Without motivation, as Gardner (1968) points out, "even the brightest learners are unlikely to persist long enough to attain any really useful language proficiency". This motivating psychological factor might not be the panacea, but it can definitely help and enhance a successful foreign language process. Having a positive attitude towards learning a foreign language can minimise negative attitudes towards the language and lessen the number of dropouts. Within motivation our study centres on intrinsic motivation, understood as somebody's internal desire to perform a particular task itself or the sense of satisfaction in completing or even working on a task (Venkatesh 1999).

The objectives of this research are twofold. On the one hand to check the degree of intrinsic motivation in Spanish students learning EFL in two different educational settings within the same age range, that is, vocational training courses and first year university students. On the other hand, to get valuable and qualitative information about how effective and motivating the language methodologies used are for students.

\section{Method}

Thirty-eight students learning English as a foreign language were surveyed. Twenty students (18-23 years old) enrolled in an English Trade course within a vocational training module in a high school. Eighteen first year university students enrolled in the English for Health sciences subject were also asked. In both cases English is taught in a specific context (ESP), the former Trade and Commerce, the latter Health Sciences (see Table 1).

Table 1. Educational centres and number of students surveyed.

\begin{tabular}{|c|c|c|c|c|}
\hline Group & \# students & Age & Course & Level \\
\hline A & 20 & $18-23$ & $\begin{array}{c}\text { English Trade } \\
\text { Course }\end{array}$ & $\begin{array}{c}\text { Secondary } \\
\text { education }\end{array}$ \\
\hline B & 18 & $18-21$ & $\begin{array}{c}\text { English for } \\
\text { Health Sciences }\end{array}$ & Higher education \\
\hline
\end{tabular}

Two questionnaires have been developed in order to survey these two groups of students in different educational institutions following Dörnyei’s (2010) argumentation in favour of questionnaires as research instruments. Students were asked to answer a first survey (S1) including 17 items or questions in a ranging scale from I totally agree to I totally disagree, the survey includes questions such as: Q6. El libro me aburre, quiero hacer actividades más dinámicas con mis compañeros/The 
book is boring, I would prefer to do more dynamic activities with my classmates , Q13. No creo que sea necesario aprender lenguas extranjeras. Debería ser optativo/Learning a foreign language should be elective not compulsory, or Q16. Participaría más si los ejercicios fueran en grupo y de "speaking", me canso de tanto escribir/ I would participate more if activities were in group and spoken, I get tired of writing (see Appendix). The second survey (S2) included 10 questions, wh-questions and yes-no questions, where students had to answer more subjectively facilitating us qualitative results. The S2 questions are:

1. How do you prefer to work in the language classroom, individually or in groups?

2. Do you think you learn more working mainly in groups? Why?

3. What do you think about the combination of the course book with other teaching materials?

4. Do you think that your lack of motivation regarding the Foreign Language is maybe due to the teacher's attitude?

5. Does the teacher present the activities in an attractive way making use of the new technologies (ICTs)?

6. Is working in groups and doing speaking activities with your classmates important to you to improve you language learning?

7. Do you consider relevant the use of the new technologies (videos, on-line activities) or other resources as useful learning tools in the classroom? Why?

8. Do you feel more comfortable and confident working with the course book in class? Yes? No? Which other materials would you suggest?

9. Do you like working with everyday life situations? Would your learning process be more successful if working with the spoken language and real life situations?

10. Do you feel motivated to continue your Foreign Language learning process or, on the contrary, you feel you are not going to improve anymore?

Both groups answered the surveys (S1, S2). They were given the option to answer the S2 questions in Spanish as to feel more comfortable and confident explaining their feelings and attitudes towards the language learning environment; we did not want students to feel unease or transmit the idea that their English level was going to be assessed or analysed from the surveys, it could interfere their answers.

\section{Results and Discussion}

An overview of the results obtained show remarkable similarities between the groups in both surveys. However, a closer look to questions revealed certain teaching aspects that deserve special attention. Regarding S1, Figure 1 below illustrates the most relevant answers in questions $6,7,13$ and 17. 


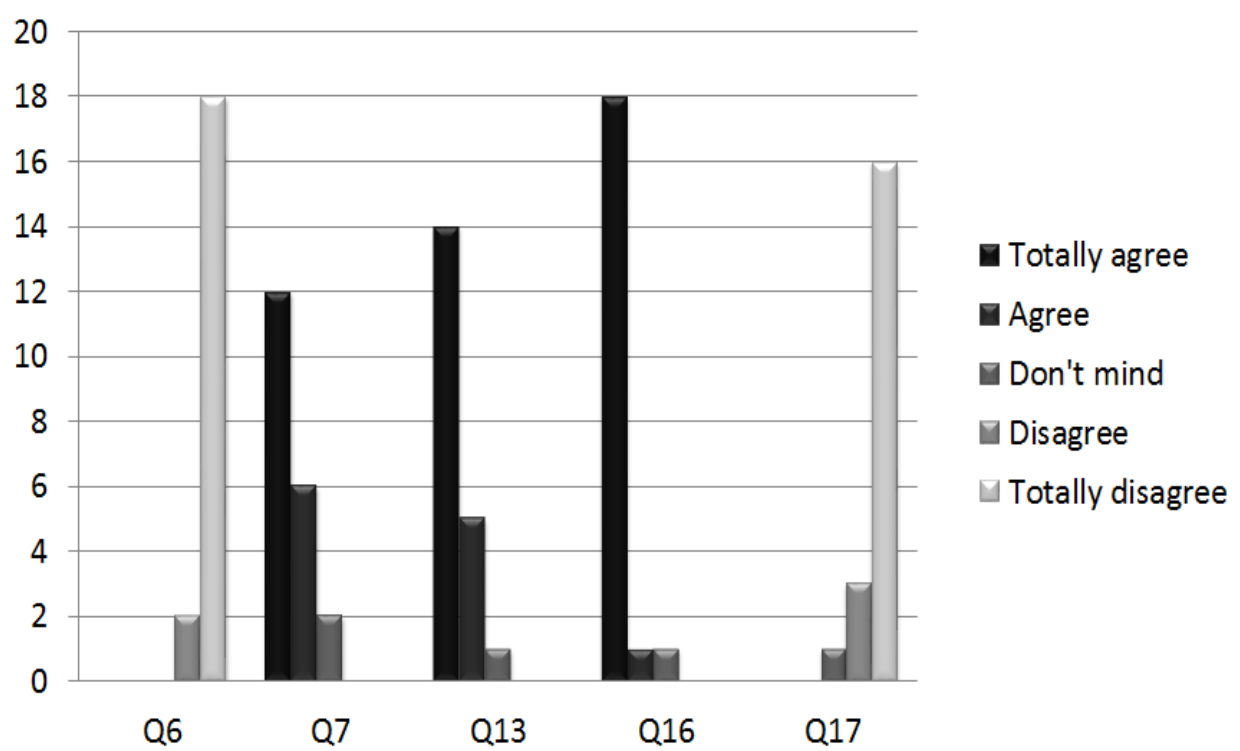

Figure 1. Group A most relevant results from S1.

As to question 6 (Q6): The teacher is not creative and he/she does not present the activities in an attractive way making use of new technologies; the students in Group A answered overwhelmingly, 18 out of 20 strongly believe that the activities are not presented in an attractive or motivating way. In Q7 they mostly answered positively to the statement: I prefer working in groups and using spoken language because that would be better for my learning process. In Q13 the student was asked: I consider really important the use of new technologies as well as the use of other relevant materials as useful learning tools in the classroom; most of them strongly or simply agree with the importance of using ICTs in the language classroom. Regarding Q16, that is, I would find English lessons more useful if we practiced the spoken language and with real life materials, the vast majority totally agreed to this idea, which makes us believe that spoken language activities are rarely presented in the English classroom. Q17 results are also relevant since nearly all the students totally disagree (16 out of 20) or disagree with the statement: I feel that in every English class I learn more and that makes me continue learning. This last item underlines the low level of motivation among the students in the Foreign Language learning process in Group A.

The results obtained in the second group (Group B) are quite similar to those obtained from the vocational training group (see Figure 2 below). However, there are some differences worth to mention. For example, the answers for Q6 are mostly opposed to Group A. In this case, 15 of 18 students totally or simply agree with the teacher being creative and using dynamic materials. Another outstanding difference with Group A occurs in Q17 where the majority of the students fully or simply agree to the statement I feel that in every English class I learn more and that makes me continue learning, and no one feels giving up learning English. This shows a high degree of motivation among group $\mathrm{B}$, first year degree students. There might be a close relation between this question and Q6 regarding the use of motivating activities in the language classroom by the lecturer. 


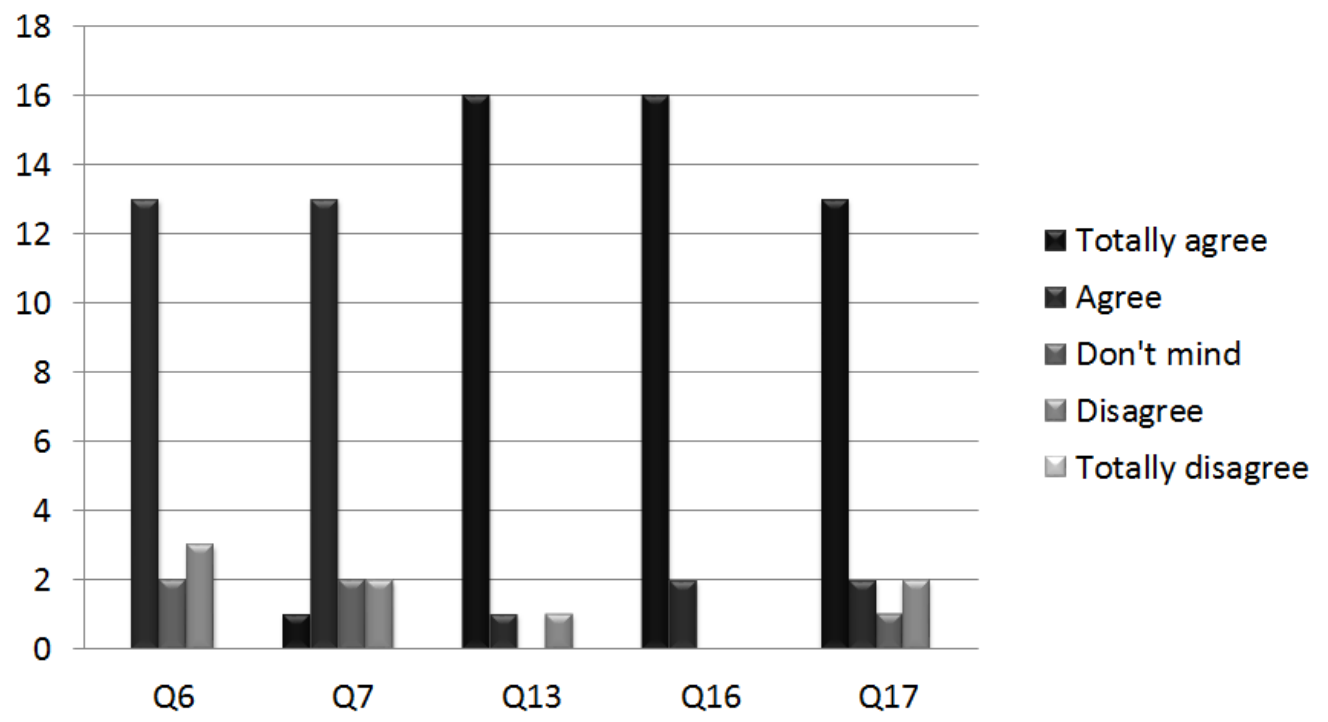

Figure 2. Group B most relevant results from $\mathrm{S} 1$.

As to S2, the majority of the students in Group A wrote comments highlighting their likeness towards group work and cooperative activities, they consider the textbook should be a help but not the only material used in the classroom. For example, one student wrote: "I prefer to work cooperatively rather than individually, I can learn from my classmates". Another student said: "The textbook should be a kind of help in class but not the only material used. There're many other resources that we could use.” When they were asked Q10, Do you feel motivated to continue your Foreign Language learning process or, on the contrary, you feel you are not going to improve anymore?, they wrote comments such as: 'I feel completely stuck', 'I can't learn anymore English', 'I need a change, something that could motivate me, I don't feel like improving."

Group B feels highly motivated and eager to learn as the answers from S2 show. When answering to Q10 they wrote comments such as: "I'd like to improve my English level in the following years", "I'd like to have a native-like level of English". This group seems also to be satisfied with the different materials used in the classroom.

\section{Conclusions}

Based on the results obtained from the surveys and the students' comments, one may conclude that foreign language learning success is not only a matter of how much students are motivated rather of how rejection towards the learning of a foreign language can be avoided. Relevant methodologies in which students feel they have an active role in the learning process should be considered. The development of lesson plans, innovative and attractive activities according to students' interests and topics which are close to their social environment, adaptation of course books and the upgrading of materials are some of the actions that should be carried out if we are to change the EFL landscape in Spanish educational institutions.

We aimed at showing the need to enthuse and motivate our students for a successful and fruitful learning process and to find the tools that can arouse students' motivation in the process of learning a foreign language for a specific purpose and try to overcome students' difficulties and rejection towards the English language learning. 
Motivation seems to be more visible among higher education students, maybe due to better and more effective methodologies and use of materials by the university lecturer or maybe due to higher future expectations among university students that see, in mastering a foreign language, a more prosperous future employment in Spain or abroad. Already in 2010, Oxbrow and Rodríguez carried out some research about motivation with Spanish tertiary level learners to see how motivation could be influenced by strategy training. They concluded that intrinsic motivation is crucial for the development of leaner's autonomy.

Regardless the profile of a student, the truth is that lack of motivation in the foreign language classroom leads to lack of effort and ultimately lack of learning success. Therefore, motivating EFL students should be paramount to teachers/lecturers.

\section{References}

Carrió-Pastor, M. L. \& Mestre, E. (2014). Motivation in Second Language Acquisition. Procedia-Social and Behavioural Sciences, 116, 240-244.

Dörnyei, Z. \& Taguchi, T. (2010). Questionnaires in second language research. Construction, administration and processing. New York, UK: Routledge.

Dörnyei, Z. (2001). Motivational strategies in the language classroom. Cambridge: CUP.

Dörnyei, Z., \& Schmidt, R. (Eds.). (2001). Motivation and second language acquisition. Honolulu, HI: University of Hawai'i, Second Language Teaching and Curriculum Center.

European Commission 2014. Erasmus + Programme 2014-2020. Retrieved from http://ec.europa.eu/dgs/education_culture/index_en.htm

Gardner, R. C. (1968). Aptitude and motivation: Their role in second-language acquisition. TESOL Quarterly, 2, 141-150.

Gardner, R. C. (2001). Integrative motivation and second language learning: practical issues. Journal of Foreign Language Education and Research, 9, 71-91.

Gardner, R.C. (2007). Motivation and second language acquisition. Porta Linguarum. 8, 9-20.

Ministerio de Educación, Cultura y Deporte. Objetivos educativos europeos y españoles. Estrategia educación formación 2020. Informe 2013. Retrieved from http://www.mecd.gob.es/dctm/inee/indicadoreseducativos/informeet20202013.pdf?documentId=0901e72b81732dc8

Nocon, H. (1991). Attitude and motivation of beginning students of Spanish at a border university. Unpublished Master Thesis. San Diego State University, CA.

Oxbrow, G. \& Rodríguez, C. J. (2010). Language learning motivation and leaner autonomy: Bridging the gap. Revista Canaria de Estudios Ingleses, 61, 57-72.

Robinson-Stuart, G. \& Nocon, H. (1996). Second culture acquisition: Ethnography in the Foreign Language classroom. The Modern Language Journal, 80, 431-449. doi: 10.1111/j.1540-4781.1996.tb05463.x

Summaries of European Legislation. EUR-Lex. Access to EU law. Education and Training 2020 (ET 2020). Retrieved from

Venkatesh, V. (1999). Creation of favourable user perceptions: Exploring the role of intrinsic motivation. MIS Quarterly, 23 (2), 239-260. 


\section{Appendix: Survey 1, Students' Motivation Questionnaire}

\begin{tabular}{|c|c|c|c|c|c|}
\hline & 1 & 2 & 3 & 4 & 5 \\
\hline $\begin{array}{l}\text { 1. I consider a waste of time having to learn a Foreign Language. It should be } \\
\text { optional. }\end{array}$ & & & & & \\
\hline $\begin{array}{l}\text { 2. If something does not appear in the exam I do not make an effort to } \\
\text { understand it. }\end{array}$ & & & & & \\
\hline 3. I would participate more in class if we worked with dynamic activities. & & & & & \\
\hline 4. I only want to pass the exam. Why do I need getting better marks? & & & & & \\
\hline $\begin{array}{l}\text { 5. When the English teacher explains something in class that I do not } \\
\text { understand, I almost always ask her/him. }\end{array}$ & & & & & \\
\hline $\begin{array}{l}\text { 6. The teacher is not creative and he/she does not present the activities in an } \\
\text { attractive way making use of new technologies. }\end{array}$ & & & & & \\
\hline $\begin{array}{l}\text { 7. I prefer working in groups and using spoken language because that would } \\
\text { be better for my learning process. }\end{array}$ & & & & & \\
\hline 8. I like that everybody knows I'm good at English. & & & & & \\
\hline $\begin{array}{l}\text { 9. I like Foreign Languages. I know they are important and I would like to be } \\
\text { able to speak English perfectly. }\end{array}$ & & & & & \\
\hline 10. I already know what my professional specialisation will be in the future. & & & & & \\
\hline $\begin{array}{l}\text { 11. When I get lost in the teacher's explanations I do not try to understand } \\
\text { him/her again. I simply 'disconnect'. }\end{array}$ & & & & & \\
\hline 12. P I always participate in the activities that the teacher suggests in class. & & & & & \\
\hline $\begin{array}{l}\text { 13. I consider really important the use of new technologies as well as the use } \\
\text { of other relevant materials as useful learning tools in the classroom. }\end{array}$ & & & & & \\
\hline $\begin{array}{l}\text { 14. I get bored when using the textbook in the classroom. I want to work with } \\
\text { more dynamic activities with my classmates. }\end{array}$ & & & & & \\
\hline $\begin{array}{l}\text { 15. I would participate more in the English classroom if the activities were } \\
\text { more dynamic. }\end{array}$ & & & & & \\
\hline $\begin{array}{l}\text { 16. I would find English lessons more useful if we practiced the spoken } \\
\text { language and with real life materials. }\end{array}$ & & & & & \\
\hline $\begin{array}{l}\text { 17. I feel that in every English class I learn more and that makes me continue } \\
\text { learning. }\end{array}$ & & & & & \\
\hline
\end{tabular}

